\title{
« Magnifying the Lord »
}

Prophetic Voice in La Cité des Dames

Lori J. Walters

\section{(2) OpenEdition}

\section{Journals}

Electronic version

URL: https://journals.openedition.org/crm/771

DOI: $10.4000 / \mathrm{crm} .771$

ISSN: 1955-2424

Publisher

Honoré Champion

\section{Printed version}

Date of publication: 30 December 2006

Number of pages: 239-253

ISSN: 1272-9752

\section{Electronic reference}

Lori J. Walters, "« Magnifying the Lord »", Cahiers de recherches médiévales [Online], 13| 2006, Online since 27 November 2009, connection on 15 December 2022. URL: http://journals.openedition.org/ crm/771 ; DOl: https://doi.org/10.4000/crm.771 


\section{RM}

\section{«Magnifying the Lord» Prophetic Voice in La Cité des Dames}

This study deals with one of my ongoing concerns, the way that Christine de Pizan portrays herself as the voice of the body politic, a voice endowed with the spirit of prophecy capable of ensuring the present and future well-being of the nascent nation-state of France ${ }^{1}$. Despite her twofold remove from the seats of power, being a woman and of foreign birth, Christine manages to create a voice having the authority to advise those governing the realm at a time when the king's voice was ailing or inarticulate. My focus will be on the prophetic frame of Le Livre de la Cité des Dames of $1405^{2}$, which is constituted by references to the Annunciation, the Magnificat, and Augustine's City of God (De civitate dei or Civitas) ${ }^{3}$.

\section{Summary of Argument}

In La Cité des Dames Christine attempts to ally her voice with the spirit of prophecy that has animated human history since the beginning of time ${ }^{4}$. Her references to sacred scripture and to Augustine, the monarchy's highest authorities, strengthen Christine's claim to incarnate a voice that transcends the limitations of her earthly body. This is the voice of the City of God, a voice that has often expressed itself through women's bodies in the past. The example most pertinent to Christine's early fifteenth-century context is Mary, whom Augustine calls a prophet in his Civitas and Trinity. Mary represented the human face of the Church, the person who initiated Christian history through her verbal assent to become the fleshly vehicle of the Incarnation.

Christine relates Mary's life story to her own by composing an allegorical narrative in which she casts herself as the protagonist. In the Cité's opening pages,

\footnotetext{
${ }^{1}$ This paper was originally given as a plenary address at the Fifth International Christine de Pizan Society Conference, which was held in Salzburg, Austria from July 17-21, 2003.

${ }^{2}$ Earl Jeffrey Richards, ed. and Patricia Caraffi, trans., La Città delle Dame, Milan, Luni Editrice, 1997. I have consulted the English translations of Earl Jeffrey Richards, The Book of the City of Ladies, 1982, New York, Persea Books, 1998, and of Rosalind Brown-Grant, The Book of the City of Ladies, London, Penguin, 1999.

${ }^{3}$ R.W.Dyson, ed. and trans. The City of God Against the Pagans by Augustine. Cambridge : Cambridge University Press, 1998. Consult http ://www.georgetown.edu/faculty/jod

for the Latin text of De civitate dei.

${ }^{4}$ For a recent study on the relationships between writing and prophecy, see Fabienne Pomel, "Revêtir la lettre nue : l'allégorie sous le signe du désir et du manqué », Le Nu et le Vêtu au Moyen Age, Aix : Publications de l'Université de Provence, 2001, 299-311, at p. 305. See also Jacqueline Cerquiglini-Toulet, «Fondements et Fondations de l'écrivain chez Christine de Pizan. Scènes de lecture et scenes d'incarnation », The City of Scholars : New Approaches to Christine de Pizan, ed. Margarete Zimmermann and Dina De Rentiis, Berlin, Walter de Gruyter, 1994, p. 79-96 and «Le goût de l'étude : savoir et saveur chez Christine de Pizan», Au Champ des escriptures: Third International Colloquium on Christine de Pizan, edited by Eric Hicks, with the collaboration of Diego Gonzalez and Philippe Simon, Paris, Champion, 2000, p. 597-608.
}

Cahiers de Recherches Médiévales, 13, 2006 
the protagonist Christine, speaking in the first-person person, echoes Mary's words at the Annunciation. In the third and final book, Christine introduces Mary as a character who also uses the first-person. At the work's conclusion, Christine associates herself once again with Mary as well as with the City of God. In so doing, Christine transforms her own voice into a prophetic one. The prophecies in question predict the progressive bringing to birth of the idea of the City of God in earthly societies. Despite momentary setbacks, those «slings of outrageous Fortune » that she knew all too well, Christine affirmed that the idea of the City of God was slowly but surely being realized in the noble nacion françoise. Those are the very words Christine used to refer to the kingdom of France in her biography of Charles V of 1404, Le Livre des Fais et Bonnes Meurs du Sage Roy Charles V, hereafter Charles V'. My study, I believe, provides a new way of envisioning the relationship between prophecy and national identity.

Christine's Imitation of Mary: References to the Annunciation and the Magnificat in the Frame of La Cité des Dames

Several critics, including V. A. Kolve ${ }^{6}$, Maureen Quilligan 7 , and Rosalind Brown-Grant ${ }^{8}$, have discussed the references to the Annunciation in La Cité des Dames. In an early scene, Christine becomes dejected when she realizes how extensively male authorities have disparaged woman's good name. She is roused from her depression by a ray of light shining down into her lap.

En celle dolente pensee ainsi que je estoie, la teste baissee comme personne honteuse, les yeulx plains de larmes, tenant ma main soubz ma joe accoudee sus le pommel de la chayere, soubdainement sus mon giron vi dessendre un ray de lumiere si comme se le souleil fust, et je, qui en lieu obscur estoie ou quel, a celle heure, souleil royer ne peust, tressailli. $(1,2)$

The ray of light announces the coming of the Three Virtues, a sort of trinitarian female angel Gabriel. After telling her she is wrong to despair, these personifications, named Reason, Rectitude, and Justice, propose to help her undertake a defense of woman's honor. Christine accepts their offer, echoing the Virgin Mary's words at the Annunciation (Luke 1: 37-38) :

\footnotetext{
${ }^{5}$ In 1404 Christine refers to the kingdom of France as the «noble nacion françoise » in Le Livre des Fais et Bonnes Meurs du Sage Roy Charles V, ed. Suzanne Solente. 2 vols., Paris, Champion, 1936, 1940, chapter 1,5. See Lori J. Walters, "Christine de Pizan, Primat, and the noble nation françoise », Cahiers de Recherches médiévales, 9, 2002, p. 237-46, which is also available online at the CRM website.

${ }^{6}$ V.A. Kolve, « The Annunciation to Christine : Authorial Empowerment in The Book of the City of Ladies », Brian Cassidy, ed. Iconography at the Crossroads, Princeton, Department of Art and Archaeology, 1993, p. 171-96.

${ }^{7}$ Maureen Quilligan, The Allegory of Female Authority: Christine de Pizan's 'Cité des Dames', Ithaca, Cornell University Press, 1991.

${ }^{8}$ Rosalind Brown-Grant, Christine de Pizan and The Moral Defence of Women: Reading Beyond Gender, Cambridge, Cambridge University Press, 1999, p. 150.
} 
Si loe Dieu de toute ma puissance et vous, mes dames, qui tant honorees m'avez qu'establie suis a si noble commission, laquelle reçoy par tres grant leece. Et voycy vostre chamberiere preste d'obeir : or commandez, je obeiray, soit fait de moy selon voz paroles. $(1,7)$

Kolve has astutely likened the scene to an «annonce faite à Christine ».

What has gone unnoticed up until now, however, is that Christine couples references to the Annunciation with ones to the Magnificat. The Magnificat is the name given to Luke 1: 46-55 because its opening line states that Mary's heart magnifies or 'mirrors' the Lord. The Magnificat is the first-person song of praise that Mary expresses when she visits her cousin Elizabeth six months after the Annunciation. I quote it in its entirety, highlighting lines for later discussion :

My soul doth magnify the Lord.

And my spirit hath rejoiced in God my Saviour.

Because he hath regarded the humility of his handmaid ; for behold from henceforth all generations shall call me blessed.

Because he that is mighty, hath done great things to me ; and holy is his name.

And his mercy is from generation unto generations, to them that fear him.

He hath shewed might in his arm : he hath scattered the proud in the conceit of their heart.

He hath put down the mighty from their seat, and hath exalted the humble.

He hath filled the hungry with good things ; and the rich he hath sent empty away.

He hath received Israel his servant, being mindful of his mercy :

As he spoke to our fathers, to Abraham and to his seed forever?.

Christine echoes the Magnificat at the end of La Cité des Dames (3, 19). In this hymn of thanks that has been set to music throughout the ages, Luke describes Mary's heart rejoicing because the promises the Lord made to her ancestor, Abraham, have been fulfilled in her conception of Christ. Christine's echo of the Magnificat comes when she addresses all women, saying that they have reason to rejoice if they follow the example of the "Vierge souveraine», who when the extraordinary honor of being chosen Mother of the Son of God was announced to her, humbled herself all the more by calling herself the handmaiden of God. If they remain humble and patient, so Christine explains, God's grace will be magnified in them as it had been in Mary.

Although Christine does not mention the Magnificat by name in La Cité des Dames, we know that she had it very much in mind because she cites it in two other texts also dating from 1405. The first instance occurs in Le Livre des Trois Vertus $2,13^{10}$, where she comments on the virtue of humility by saying that Mary's humility delighted Our Lord more than her virginity, as expressed in the Magnificat : «Il regarda l'umilité de son ancelle». The second instance occurs in L'Advision Cris-

${ }^{9}$ The Douay-Rheims New Testament, 1899 ; Rockford, IL, Tan Books, 1976, p. 66. The Douay-Rheims Bible is a scrupulously faithful translation into English of the Latin Vulgate Bible, which St. Jerome (342-420) translated into Latin from the original languages.

${ }^{10}$ Charity Cannon Willard, ed. Le Livre des Trois Vertus, Paris, Champion, 1989. 
tine $^{11}$. Christine opens chapter 1,17, entitled « Du vent de perdicion qui cueurt parmi la terre », with a reference to the prophet Daniel's advision that King Nabuchodonor's pride would be humbled by the Lord. The last line of the chapter is «Et adonc sera certifie la prophecie de la Vierge qui dist: 'Deposuit potentes de sede et exaltavit humiles' ». Christine Reno and Liliane Dulac (p. 157) remark that Christine gives us here an unorthodox reading of these lines, "plutôt qu'une prophétie, ce sont les paroles de la Vierge Marie à l'occasion de l'Annonciation ». Although this may first strike us as unusual, the context of the chapter, as well as Christine's own words, indicate that she does indeed consider the Magnificat to be a prophecy.

Christine draws upon Augustine for this attribution. He cites Mary as a prophet in Civitas 17, 24 : «the Virgin Mother of the Lord is herself found to have prophesied before John did ». He makes direct reference to the Magnificat in Trinity 4, 29 with the words, «Mary [was] filled with the Holy Spirit to proclaim the praise of the Lord she was carrying in her womb». In passages surrounding these examples Augustine places Mary in a line of prophets along with Zechariah, Elizabeth, John the Baptist, Simeon and Anna. In citing this series of prophets, Augustine expresses the notion that the Holy Spirit expressed itself in the world before Christ's birth. By failing to take into account the echoes of the Magnificat in La Cité des Dames, critics have not fully understood Christine's prophetic gesture in this text or in others.

\section{Augustine, Prophetic Voice, and the Translator}

In 3,18, the Cité's next-to-last chapter, Christine completes the Augustinian frame of her work by quoting Psalm 86.3, «Gloriosa dicta sunt de te, civitas Dei ». This was the quotation from which Augustine drew the title of his City of God, and he cited it three times over the course of his work. Augustine's central thesis in his monumental treatise (numbering over 1,100 pages in Dyson's English translation) is that Christianity, rather than destroying Rome, was the culmination of Roman values that the Romans did not even realize they had. The voice of the City of God has been speaking throughout history to lay the groundwork for the coming of a just Christian commonwealth. If Augustine maintains that this commonwealth was present in Rome at the time of Christ's birth, Christine develops his notion by claiming that it is likewise present in the once and future noble nation françoise.

As we have seen, Augustine is a major source of Christine's ideas on prophecy. In his Civitas 17, 3 he identifies three sorts of prophecy: those referring to the earthly Jerusalem, those referring to the Heavenly Jerusalem, and those that refer to both at once. He considers the prophecy relating to the City of God, which he identifies with Jerusalem itself, to be of the third type. Christine borrows the multivalent nature of Augustine's prophetic city for her own. She follows other royal ideologues in enlisting theology, the dominant discourse of the time, in their efforts to establish a better human polis. This is where Christine's hierarchy of authorities, which places Augustine on the highest, but still not entirely impregnable pinnacle, joins the hierarchy enunciated by a whole line of monarchical theorists.

${ }^{11}$ Christine Reno and Liliane Dulac, eds., Le Livre de l'Advision-Cristine, Paris, Champion, 2001. 
Christine constructs for herself a persona as translator and voice of the body politic based upon on an ongoing and dynamic «ideology of France», which recognized Augustine as one of its foremost authorities. A major formulation of this ideology is found in her biography of Charles V. ${ }^{12}$ In 3, 12 Christine describes the King's motivation for beginning his translation program, identifying his model for such an undertaking in prior vernacular translations of the Bible. Those translations had most often been made by or for royal figures (an example of the first is King Alfred who translated the first fifty psalms into Anglo-Saxon). Christine follows her description of Charles' translation campaign with a list of ten of the roughly thirty texts that Charles had adapted into the vernacular ${ }^{13}$. The first five on the list, a list arranged in descending order of importance, include two texts by Augustine and three by Aristotle. La Cité de Dieu heads the list, its title rendered in the French of its translation by Raoul de Presles, but without mentioning Raoul's name.

A quotation in Christine's Livre de Policie of 1406-07 reveals the spin she and other theorists put on Augustine. Identifying her source as Saint Augustine's Cité de Dieu, a reference that blurs the distinction between Augustine and his translator Raoul, Christine says «Augustine dit que les philosophes dient que vertu est la fin de bien et mal humain, c'est a dire que la felicité humaine est en estre vertueux » $(1,2)$. Christine here cites Augustine's authority in order to describe an ideal earthly state, one that can be attained in this life if human beings become virtuous by following Christ or noble persons who prefigure Christian virtues. Christine's statement is a crucial element that has been left out of discussions of "political Augustinianism $»^{14}$. It reveals quite clearly the use to which Augustine was put in the later Middle Ages. Political theorists took The City of God as the primary blueprint for the earthly paradise they desired to realize through what we would today call «social engineering ». Their methods included recasting the microcosm and the macrocosm, the individual and the corporate body politic, according to paradigms set forth in The City of God, usually combining them with the ideas of other authorities favored by the monarchy.

${ }^{12}$ Lori J. Walters, «Christine de Pizan as Translator and Voice of the Body Politic», Christine de Pizan: A Casebook, ed. Barbara K. Altmann and Deborah McGrady, New York, Routledge, 2003, p. 25-41 ; Lori J. Walters, «Christine de Pizan, l'idéologie royale et la traduction », tr. Renée-Claude Breitenstein, D'une écriture à l'autre. Les femmes et la traduction sous l'Ancien Régime, éd. Jean-Philippe Beaulieu, Ottawa, Presses de l'Université d'Ottawa, 2004 , p. 31-52. In her groundbreaking look at the role of translation in the emergence of vernacular literary culture in the Middle Ages, Rita Copeland shows how during Charles V's reign «the emergent power of the French language as a medium of translatio studii », authorized itself «through a material identification with royal power», Rhetoric, Hermeneutics, and Translation in the Middle Ages : Academic Traditions and Vernacular Texts, Cambridge, Cambridge University Press, 1991, p. 135.

${ }^{13}$ For the scope of Charles' translation program, see C. R. Sherman, Imaging Aristotle: Verbal and Visual Representation in Fourteenth-Century France, Berkeley, University of California Press, 1995, p. 6-9.

${ }^{14}$ The term was coined by H.-S. Arquillière, L'augustinisme politique : Essai sur la formation des theories politiques du moyen-age, Paris, 1934, 1955, 1972, to refer to the tendency of medieval Christendom to obscure the distinction between the state and the church. 
In her corpus of writings, which is exclusively vernacular, Christine synthesizes many of the works involved in Charles's translation campaign, thus tacitly assuming for herself the role of «translator». In La Cité des Dames Christine, mentioning both by name, brings together Augustine and Aristotle, the top two authorities on Charles' list, in their concern for justice. Christine conjoins their authority on the principle of justice when she has Lady Justice say that the Three Virtues culminate in her $(1,6)$, and when she establishes the Virgin Mary as the highest exemplar of justice in Book 3. But Augustine remains her highest authority in La Cité des Dames, as he was in Charles' translation campaign, where The City of God was the work having the greatest authority after the Bible. Now, this seems to be a simple, even simplistic, point. But two otherwise superb studies, Claire Richter Sherman's Imaging Aristotle and more recently Carra Ferguson O'Meara's Monarchy and Consent $t^{15}$ fail to appreciate Augustine's position as number one monarchical authority. This comes to the fore in La Cité des Dames when Christine implicitly uses Augustine to counter the Aristotelian view of the female as a defective male ${ }^{16}$.

Augustine is Christine's highest authority, as he is for the late medieval French monarchy. This is shown when she refers to him as «ce saint luminaire au front de saint Eglise qui toute l'esclaire et enlumine»(Cité 1, 10). Christine here casts Augustine as a «figure de proue», a beacon guiding the Church, represented as a ship, often as the ship of King Solomon. Christine cites Augustine in this way to bolster her authority as monarchical counselor. Her implicit contention is that she is qualified to guide the ship of church and state through troubled waters because she is so well versed in official ideology that she deserves the status of monarchical translator.

Christine, following Charles V, draws her self-conception as translator from Augustine. He sets forth his ideas on the exalted role of translator in Civitas 18, 43 : "Of the authority of the Septuagint translation, which, with the exception of the Hebrew original, is to be preferred to other versions ». The chapter deals with the effort of King Ptolemy Philadelphus to enlist the Jews in having the Septuagint translated from Hebrew into Greek. Augustine concludes by saying: «And they received so wondrous a gift of God precisely so that, by means of it, the authority of those Scriptures might be commended not as human, but as divine, to the Gentiles, who were to come to believe in Christ : a purpose which, as we see, has now been accomplished ».

Christine draws heavily upon Civitas 18, 43 in describing Charles V's translation campaign. For example, in Charles V 3, 12 she postulates the same Ptolemy Philadelphus as Charles V's predecessor. In another example, in this chapter Christine also cites Augustine to the effect that the translations of the seventy-two translators, all working separately, turned out to be exactly the same. When she adds «laquelle chose estre no pot sanz miracle de Dieu», she reinforces the Church Father's point that the Holy Spirit was working through them all. Christine likewise follows Augustine in equating translators and prophets. In La Cité des Dames Christine builds upon the Church Father's ideas by showing that she, like earlier Biblical

\footnotetext{
${ }^{15}$ Carra Ferguson O'Meara. Monarchy and Consent : The Coronation Book of Charles V of France, British Library MS Cotton Tiberius B.VIII, London, Harvey Miller, 2001.

${ }^{16}$ Brown-Grant, p. 150.
} 
and French translators and prophets, is animated by the voice of the Holy Spirit. In order to avoid sounding proud, Christine refrains from making the claim outright, and in this, she again closely follows Augustine. According to Christine, the translator can and should become a prophet who humbly but surely guides the monarchy according to God's divine plan.

\section{Augustine's Defense of Woman and of Mary}

Christine bases her defense of woman on Augustine. This can seem odd, since we typically regard him as antifeminist. But as Jeff Richards ${ }^{17}$ and BrownGrant $^{18}$ point out, and I believe correctly, Christine puts the "glorieux docteurs » clearly on the side of women's defenders. The Danish theologian Kari Børresen emphasizes that compared to other Church Fathers, Augustine in his time was considered a champion of woman's equality with $\operatorname{man}^{19}$. And it is this interpretation that Christine emphasizes in her works. Christine clears tells her readers that she is interpreting Augustine as a defender of Mary and of women in her Oroyson Nostre Dame of $1402-1403^{20}$. She affirms that Mary was predestined to be a virgin way before her birth «Ainsi le dit saint Augustin/ De la Trinité ordennée » (vv. 51-52). In this same work she cites Augustine for the claim that Mary is the queen who enables humanity to take away the sin of Eve (vv. 73-75).

But most importantly, Augustine proves to be women's prime defender when our lawyer-like Christine puts the body on trial in La Cité des Dames. This is the charge brought against the female sex: «tous accordent une semblable conclusion, determinant les meurs femenins enclins et plains de tous les vices ». Christine then begins a period of self-examination: «je pris a examiner moy mesmes et mes meurs comme femme naturelle» $(1,1) . \mathrm{A}$ «femme naturelle» is a loaded term. It refers to Civitas 22, 17 in which Augustine affirms, and against opinions to the contrary, that woman's body will retain its sex at the resurrection, just as will man's. He supports his argument with the claim that «the sex of a woman is not a vice, but nature». When Christine calls herself a «natural woman », she invokes a piece of wisdom that must have been well known in court circles which considered The City of God to be their highest authority after the Bible itself.

Even more remarkably, Augustine not only provides Christine with a defense of women, but he additionally provides the method for transforming the natural body into a virtuous one. In Civitas 22, 17 he goes on to add that the natural human body has to be «edified » to virtue through the efforts of the Church. ${ }^{21}$ In Augustine's

\footnotetext{
${ }^{17}$ Earl Jeffrey Richards, «In Search of a Feminist Patrology : Christine de Pizan and les Glorieux Dotteurs », in Une femme de Lettres au Moyen Age: Études autour de Christine de Pizan, eds. L. Dulac and B. Ribémont, Paris, Paradigme, 1995, p. 281-295.

${ }^{18}$ Brown-Grant, p. 144.

${ }^{19}$ See the discussion in Lori J. Walters, «La réécriture de saint Augustin par Christine de Pizan : De la Cité de Dieu à la Cité des Dames ", Au Champ des escriptures : Actes du IIIe colloque international sur Christine de Pizan, Lausanne, 18-22 juillet 1998 (Études christiniennes 4), Paris, Champion, 2000, p. 197-215.

${ }^{20}$ Maurice Roy, éd., Euvres poétiques de Christine de Pisan, 3 vols., Paris, Didot, 18861896, Johnson Reprint Corporation, 1965, t. 3, p. 1-9.

${ }^{21}$ IDevelop this argument at length in «Christine de Pizan, l'idéologie royale et la traduction».
} 
eyes, woman's body is equivalent to man's body, both in its initial sinfulness, and in its potential to be edified. For Augustine, Eve represents the representative human body that each one of us must reshape according to the Church's doctrines. Christine returns to this point in the opening line of Le Livre de Policie of 1406-07 when she says : « Se il est possible que de vice puist naistre vertu, bien me plaist en ceste partie estre passionnee comme femme $\aleph^{22}$. Her passion is to help others transform their sinful human flesh into an image of virtue. She apostrophizes virtue a few lines later as «chose digne et deifiee». Virtue is not only a worthy thing. When human beings make themselves into images of «virtue personified», they approximate the very image of God on earth.

As it had been for Augustine, Christine too sees Christian history dominated by the image of a virtuous Mary rather than by that of a sinful Eve. According to Christine, this image should also dictate contemporary woman's self-image. She makes this clear when, at the opening of Book 3 of La Cité des Dames, she has the Virgin proclaim « Si suis et seray a tousjours chief du sexe femenin ». Christine has prepared her readers for Mary's triumphant appearance on the scene here by her discussion in 1, 9. There she had affirmed that human superiority is determined not by sexual difference but by the degree to which one has perfected one's nature and morals, adding that humankind gained far more from Mary than it had lost through Eve. Christine emphasizes that Mary transformed her natural body into an image of Virtue, when, again at the beginning of Book 3, she has the Virgin, speaking in the first-person, accept the invitation of the three personified Virtues to enter the highest towers of the City of Ladies. To the Three Virtues of Reason, Rectitude, and Justice, Christine adds a fourth personification, Nature, who tacitly becomes a fourth Virtue. Christine thereby expresses two notions: the first, that Nature is the Trinity's handmaiden in the world; the second, that Mary reflects or magnifies the Lord in being a morally perfect image of the natural human body (the microcosm) and the natural universe (the macrocosm).

This interpretation of the «natural woman » was implicit from the beginning of La Cité des Dames, where Christine encases her references to Augustine's greatness with one on the role of Monnica's tears and prayers in bringing her son to his high position in the Church, a fact to which he testifies in his Confessions ${ }^{23}$. With her allusions to Monnica, Christine lays the foundations for her connections between the word and example of holy mothers like Monnica and Mary and the role of the Church in bringing the natural human body of the faithful to a state of sanctity. Christine thus establishes one of her main points - that all people are influenced by their mother's words and example, just as they are influenced by Holy Mother Church - on Augustine's authority. The connections Christine establishes between Augustine and the Virgin Mary in La Cité des Dames are based upon the idea that the City of God, in Augustine's treatise as in Psalm 86 from which he draws his

\footnotetext{
${ }^{22}$ Angus J. Kennedy, ed., Le Livre du Corps de Policie, Paris, Champion, 1988. All references will be to this edition.

${ }^{23}$ Henry Chadwick, trans., Saint Augustine : Confessions, Oxford, Oxford University Press, 1998. All references will be to this translation. I adopt the spelling of Monnica's name suggested by Garry Wills, Saint Augustine, New York, Penguin, 1999, p. 2.
} 
conception of it, is a female figure. Augustine refers to her as «Mother Sion», Sion being another name for Jerusalem.

\section{Prophecies Concerning the City of God and «Mother Zion »}

Before arriving at «Mother Sion» in Civitas 17, a book devoted to prophecy, Augustine $(17,4)$ discusses Hannah's conception of the future prophet and judge Samuel after many years of barrenness, as recounted in I Sam. 2, 1ff ${ }^{24}$. He interprets Hannah as a symbol of the Church and as a forerunner of Mary. He makes it clear that the Magnificat was prefigured in Hannah's song of praise. The Magnificat echoes Hannah's «My heart rejoiceth in the Lord [. . .], my mouth is enlarged over mine enemies ; because I rejoice in Thy salvation ». This is how Augustine interprets Hannah's prayer of thanks: "Can anyone doubt that through this woman (whose very name Hannah, means 'God's grace') there speaks the Christian religion itself, the City of God itself, whose King and Founder is Christ?» With these words, he claims that Hannah expresses something that goes beyond her status as a female body. She speaks with the voice of Mother Sion, which is the voice of the City of God itself ${ }^{25}$. Informing us that the word «Sion» means contemplation, Augustine identifies Mother Sion as the voice of the Church that was heard throughout human history, even before the actual Catholic Church existed.

We now come to the crux of my argument about the relationship between the City of God and the City of Ladies. This is something that escaped me when I first wrote on the question ${ }^{26}$. Mother Sion - the queen of cities, according to Augustine, is the prototype, or more rightly the matrix, of all Christian cities. In this sense, the Christian city was, and always will be, a city of Ladies. Christian queens were known for leading their societies to sanctity by inspiring their husbands and sons to convert and establish Christianity as the state religion. In Cité 2, 35 Christine recounts how Clothilde's tears persuaded her husband Clovis to become the first Christian king of France. Clothilde's story parallels that of Helen (mentioned in Cité 3,18 ), whose tears inspired her son Constantine to institute Christianity as the official religion of the Eastern Empire. Christine points out that it is because of Clothilde that the kings of France are known as «most Christian». If it is true that

\footnotetext{
${ }^{24}$ After gaining a stunning victory over the Philistines, Samuel inaugurated the line of kings in anointing first Saul, and when Saul proved unworthy, David. Although David was the prototype of all Christian kings, the association between David and French kings was a special feature of French royalty beginning with Charlemagne.

${ }^{25}$ In Civitas 17, 17, Augustine sums up his interpretation of psalm 86 in the following way : " And thus Christ, Who is God, before He was made man through Mary in that city [the City of God], Himself founded it through the patriarchs and prophets. Thus, what we now see fulfilled was long ago said in prophecy to this queen, the City of God : 'Instead of thy fathers, sons are born to thee ; thou shalt make them princes over all the earth' (Ps. 110, 1f). For, truly out of her sons have come forth her leaders and princes throughout all the earth, and the people, gathering together in her, confess her with the confession of eternal praise for ever and ever ». The original « confession of eternal praise » of the City of God was recast in Hannah's song, in psalm 86 (the psalmist David was Mary's ancestor), in Mary's Magnificat, and in Christine's City of Ladies.

${ }^{26}$ Walters, «La réécriture... ».
} 
human beings must cooperate with the will of the Holy Spirit in order to create the City of God on earth, it is also true that in the past many women communicated that will to others. Chief among those women were Christian queens, who did so by modeling their conduct upon Mary's acceptance of God's will at the Annunciation. It follows that in a very real sense everyone must imitate Mary's example as a redeemed figure of Eve in order to give birth to the spiritual person who risks lying stillborn in their carnal selves.

This is a prime concept in Civitas 22, 21, where Augustine, in a gloss on Paul, 1 Cor. 15, 44, says: «It is sown an animal body, it will rise a spiritual body». To understand the meaning of this phrase, we have to remember that both men were heavily influenced by Platonism. Rather than referring to the transformation of the physical body, Paul and Augustine are talking about transforming the mental image of the body, which is equivalent to the individual body politic. It helps to recall, thanks to the gloss that Christine Reno discovered in manuscript Ex-Phillips 128, that Christine singles out Augustine and Paul as « grant augmenteur de l'Eglise et de foi catholique» (1. 234-35). What she prizes is the strength of their evangelizing, Pentecostal word, a strength that she desires to emulate by placing her rhetorical skills at the service of a monarchy considered to be divinely ordained.

The notion of spiritual transformation set forth by Paul and developed by Augustine is a paramount one for Christine as it was for other monarchical theorists. The notion applies to the nation as well as to the individual. Christine's first-person speaking self resembles the Biblical first-person in which a greater equivalence exists between the individual and the larger collectivity than what we find in modern times. In quoting from Psalm 86 at the conclusion of her Cité des Dames, Christine predicts, and in predicting helps to bring about, the accomplishment of the prophecy of the coming of a Christian community here on earth established on the model of the City of God. In mentally reformulating the prophecy about Sion, which we recall means «contemplation», Christine as it were cooperates with the Holy Spirit in helping to bring to birth the idea of the noble nation françoise that monarchical theorists had been hatching for centuries.

Christine, the reader, and a living, speaking Mary all meet in La Cité des Dames, a locus set off from humans' normal time-space coordinates. Into the «inner theater of the mind » of her audience Christine introduces the concept of the City of Ladies as a City of God maintained by Christian queens. She thus encourages her readers to work together with the present queen Ysabel, whom Christine addresses by name in 2, 68, in order to bring about the realization of the concept in real life. And her City of Ladies holds special meaning for Ysabel as the earthly embodiment of the City of God in contemporary France. The idea will also live on in Christine's textual city to guide future generations of queens and their subjects.

\section{«Performing the Prophecy » concerning the City of God}

To appreciate the full force of Christine's prophetic gesture, we have to think about what a prophecy represents. A prophecy is a word that comes to pass in reality. The word precedes its realization in objects. Following Augustine, who in his Civitas 17, 3 actually speaks of "performing a prophecy », Christine performs the prophecies encoded in Psalm 86 and in the Magnificat in several ways. First, she performs them by remembering them in a way that is relevant to a precise historical 
context. This implies rewriting them in a new form. In composing her La Cité des Dames, she recasts a whole line of prophecies reaching back to the original one in Psalm 86. Its punch line, 86.3, «Glorious things are said of thee, City of God ${ }^{27}$, is a piece of reported speech that expresses a universal desire for a place of peace and justice for all.

Christine couples the prophecy about the City of God with the prophecy of the Magnificat. Mary's song of rejoicing celebrated the fulfillment of Old Testament prophecies in her conception of the Christ Child. Mary's conception of Christ in her womb came about as a result of her understanding of, and of her belief in, the prophecies about his birth. Augustine had emphasized this point by claiming that Mary first conceived Christ in her mind and heart before conceiving him in her womb: «Fides in mente, Christus in ventre ${ }^{28}$. Christine is a Mary figure in her role as writer who mentally conceives of the City of Ladies before she brings it to birth. The celebratory, Magnificat-inspired rejoicing at the Cité's conclusion signifies that she has achieved the conception of the City of Ladies by writing her book, her textual incarnation of the City of God. Christine will often, as she does in L'Advision Cristine $(3,10)$, return to the metaphor of producing books from the womb of her mind. But the prophecies celebrated in La Cité des Dames are communal ones. In order for them to be fully realized, others have to read and understand her book, and they have to act out its prophecies in their own lives. Christine establishes her persona as the model for the performance, by her readers, of the prophecy concerning the City of God. She does this by representing her protagonist Christine as an Eve figure-in-the-process-of-becoming-Mary. At the beginning of the work Christine contemplates the judgment that men have passed upon women throughout the ages: «les meurs femenins [sont] enclins et plains de tous les vices $(1,1) »$. With her head bowed in shame and her eyes filled with tears, Christine is a figure of a remorseful Eve about to be expelled from the earthly paradise. Over the course of the narrative Christine transforms the face of her protagonist from an image of the sinful Eve into one of the virtuous Mary, who, we recall, appears in person to give a short speech at the beginning of Book 3. At the work's ending Christine's protagonist comes to speak with the authority of a redeemed human body. Christine's transformation of her protagonist has important implications for her own function as author. Since by the Cité's conclusion Christine's voice and the voices of Mary and the personified Virtues have become virtually one and the same, the pedagogical stance she has assumed throughout the narrative receives strong reinforcement. By asserting her own authority in this way, Christine encourages her readers to undertake a similar trajectory of self-improvement.

It is by means of Augustine's conceptions of the text-as-mirror and Mary as the reflection of the Trinity that Christine is able to «perform the prophecy » about Mother Sion and the City of God. What is meant by the text-as-mirror only becomes clear by experiential proof in front of a real mirror. If we write the letters EVA on our forehead and look at ourselves in a mirror, the reflection gives back the reading

${ }^{27}$ This line was supposedly said by David, the Christian king's prototype and Mary's ancestor.

${ }^{28}$ Allan D. Fitzgerald et al., ed., Augustine Through the Ages : An Encyclopedia, Grand Rapids, MI, Eerdmans Publishing, 1999, p. 544. 
AVE, the first word said to Mary by Gabriel. Christine's text-as-mirror, complete with a living, speaking Mary, invites the reader to compare her or his image with Mary's, an example with a fixed moral valence. This is true whether the observer is a man or a woman. As the mother of us all, Mary is the representative human being, who, unlike her son Christ, was born of two human parents. Christine's Cité des Dames is a reversing mirror. It reflects the possibility that all her readers, whether women or men, can transform themselves from sinful human beings into virtuous ones by means of their reasoning powers. Christine communicates this idea through her image of Lady Reason, who holds a mirror in her right hand :

Et puis je le leur enseigne la maniere de suivre ce qui est a faire et comment fuiront ce qui est a laissier. Et pour ce que je sers de demonstrer clerement et faire veoir en conscience et de faict a un chacun et chacune ses propres taches et deffaulx, me vois tu tenir en lieu de ceptre cestui resplandissant mirouer que je porte en ma main dextre. Si saches de vray qu'il n'est quelconques personne qui s'i mire, quelque la creature soit, qui clerement ne se congnoisce. $(1,3)$

Christine's term «creature » refers to both men and women, its gender nonetheless suggesting that the representative human being is female. The transformation from vice to virtue asked of all humans has positive value, as shown by Christine's quotation of Augustine in the Policie, not only for existence in the afterlife, but also for everyone's life here on earth. It will result in the achievement of individual human happiness and the improvement of the commonwealth ${ }^{29}$.

\section{Virtuous Mothers and the City of God}

And to those for whom Mary's example seems too difficult to imitate, Christine gives countless examples of more approachable figures. Take Semiramis, the very first «stone» posed by Christine in constructing her city of ladies. Although Semiramis was the great queen of Babylonia, she can strike us as an odd « founding mother », since she wed her own son Ninus. I think that Christine chose her as the Cité's first «stone» because although historically Semiramis is an example of a flagrant sexual transgressor, symbolically she is a pagan prefiguration of Mary, whom the Church coupled with her son in a strictly spiritual embrace ${ }^{30}$. Christine excuses Semiramis because she lived before written law. This was a time when, and

\footnotetext{
${ }^{29}$ For a study of the performance of nationhood, see my «Performing the Nation : Christine de Pizan's Biography of Charles V \& the Play Performed at the Great Feast », Cultural Performances in Medieval France: Essays in Honor of Nancy Freeman Regalado, ed. Eglal Doss-Quinby, E. Jane Burns and Bonnie Krueger, Woodbridge, Boydell and Brewer, forthcoming in 2007.

${ }^{30}$ On p. 47 of «Somewhere between Destructive Glosses and Chaos : Christine de Pizan and Medieval Theology », in Christine de Pizan : A Casebook, p. 43-56, Earl Jeffrey Richards states that she is an image of Christ: "Thus Christine sees the incestuous Semiramis as a keystone for her foundation, an angularis fundamentum lapis, as a type of Christ, rehabilitated in the name of ius naturale, to found her allegory of universal empire in the City of Ladies. As an allegorical type of Christ, Semiramis represents in Christine's political vision a new christologically sanctioned tradition of queenship ». As a human reflection of Christ, Semiramis can also be seen as a figure of Mary and of the Church.
} 
I quote, «ains vivoient les gens a loy de Nature ou il loisoit a chacun de faire sans mesprendre tout ce que le cuer lui apportoit» $(1,15)$. Christine goes on to imply that if Semiramis had lived in Christian times, she would have known how to shape her natural human instincts to virtuous use. Inspired by Christian principles, she could have transformed her inborn human nature into a morally perfect «second nature». Semiramis could have been another Blanche de Castille, who according to Christine's account $(1,13)$, was her son's head of council when he was grown, and even followed him to war. (It is significant that Christine precedes Semiramis' story with Blanche's, so that her readers do not lose sight of the Christian queen as their contemporary model.) Christine obviously has Augustine in mind when she represents the human body as something morally neutral that Christians must constantly recast as a spiritual body.

But even more brilliant than her accumulation of past examples designed to spark identification from each and every reader, is Christine's use of herself as example ${ }^{31}$. As a «natural woman», she represents the natural human body in a way that a man cannot. The idea is that if a lowly daughter of Eve can achieve sanctity, anybody can. Christine grasped and exploited to the hilt the power implicit in the Christian idea that low equals high («the first shall be last, the last first », «the proud shall be humbled», a prominent motif in the Magnificat). Since a woman is man's inferior in the order of creation ${ }^{32}$, when she transforms herself morally, her virtue becomes all the greater than a man's could ever be. By promoting herself and other virtuous women, who all have their ultimate model in Mary, Christine touts women's potentially transcendent moral authority in the world.

Christine illustrates what she means by transcendent female authority with her story about Augustine brought to sanctity by means of his mother's tears. Even a Church Father, and one acknowledged by the monarchy as society's highest authority, had to follow the example set by his mother. Christine points out, and a bit slyly I would say, that Augustine resisted Monnica's wisdom for a long time, opposing it despite Bishop and later Church Father Ambrose's praise of her virtue. While intending no disrespect to Augustine, Christine nonetheless implies that he could not have attained his stellar position in the Church if he had not followed his mother's example. Christine had already introduced this idea in her Epistre au Dieu d'amours of 1399 in contending that sons resemble their mothers. In La Cité des Dames she suggests that Augustine's conversion to Christianity was dependent upon acknowledging his mother's authority. Monnica represented the voice of the Church, and a spiritual lineage that was superior to biological lineage. In the Confessions Augustine describes Monnica's relief at learning of his conversion as a joy «far dearer and more chaste than she expected when she looked for grandchildren born of my body » $(8,30)$. The agency of the biological mother, and of Holy Mother Church acting as a spiritual mother, is a crucial element in the transformation of individual and corporate bodies into spiritual bodies that will restore humans to the prelapsarian happiness they had enjoyed in the earthly paradise.

\footnotetext{
${ }^{31}$ On this subject, see Thelma Fenster, «Who's a Heroine? The Example of Christine de Pizan », in Christine de Pizan : A Casebook, p. 115-28.

${ }^{32}$ See my «La réécriture de saint Augustin »for an analysis of the distinction between the order of creation and the order of salvation.
} 
And I do see, although I do not want to stress it here, the bind that this exalted role confers upon women. Christine was writing for a society that respected women insofar as they remained keepers of civic morality. We cannot deny that Christine represents herself, and women in general, as the consummate keepers and shapers of public morals. But she is not a dull moralizer, and she balances her moralizing with some good storytelling. Christine tempers her preaching with endearing references to her imperfect human self. While decrying France's woes in L'Advision Cristine, Christine cannot forget that her fur-trimmed coat is threadbare. She is a concerned mother who tries to talk her beautiful daughter out of becoming a nun (3, 17). She, like other women, has been defamed $(3,6)$. In these and other «autobiographical» passages of L'Advision, Christine puts into practice her advice to readers that stories should be entertaining. In Trois Vertus 1, 24 she tells us that storytellers should not appear to be teaching moral lessons even when they are doing so. Christine obviously counted upon the confessional details of her self-portrait to encourage identification in her audience. If Christine is an ideologue, she is also a skilled interpreter of human nature. In this she is an adept follower of Augustine, who went from being a successful teacher of classical rhetoric to even more successful preacher of the Christian faith.

Christine's emphasis on Monnica's words and silent, tearful example, bolstered by memory of other Christian wives and mothers, is calculated to increase Christine's own authority to be believed and imitated. Her Advision Cristine, written during the same period as La Cité des Dames and Les Trois Vertus, contained numerous allusions to her trials as wife, mother, and widow. Christine's apparently homespun lesson in La Cité des Dames is that women would do well to conform their image to that of Mary and of Holy Mother Church, and that both women and men are to follow the example of a whole line of virtuous mothers, from the lofty Mary to the lowly Christine. I qualify her lesson as «apparently homespun » because in fact it would be hard to find a more talented interpreter of monarchical ideology than Christine. Like Mary, she manages to combine two apparently contradictory qualities : she remains humble while revealing a divinely inspired intelligence.

\section{Conclusions and Further Thoughts}

We have seen that Christine's transformation of her textual persona allows her to transcend the limitations of her physical self and speak with the voice of Mary and of Holy Mother Church. Mary represents the Church who re-members Christ, who symbolically puts him back together in her memory, in order to assure his continued relevance to the ongoing evolution of the church-state alliance. Examples of Mary-as-church and woman-as-church were commonplace in Christine's time. It is obvious to me, although it seems to have escaped everyone else, that Christine patterned her Cité des Dames on Notre-Dame-de-Paris, the cathedral on the Ile-dela-Cité dedicated to Mary. Notre Dame dominated the early fifteenth-century Parisian landscape, providing the female complement to Saint Denis to the north of the city. Notre Dame is the closest one can come - after Jerusalem itself - to the concrete embodiment of the City of God on earth. A miniature in the Très Riches Heures of the Duke of Berry, one of Christine's leading patrons, shows the Magi descending on a montjoie overlooking a latter-day Jerusalem, represented as medie- 
val Paris with Notre Dame and the Sainte Chapelle clearly etched out against its skyline (fol. $51 \mathrm{v}){ }^{33}$ The Parisian cité is the symbolic heart of the realm as well as the enceinte - physical, spiritual, linguistic, and textua - from which will come future rulers, their advisors, and the citizens of the noble nation françoise. In amalgamating references to the Annunciation, the Magnificat and The City of God in her Cité des Dames, Christine performs their prophetic message yet again. And she asks her readers to continue performing it until humanity realizes its fondest dreams of a place of peace and justice for all. And today, sixteen centuries after Augustine, and six centuries after Christine, it is amazing how far we still have to go.

Lori J. Walters

Florida State University/USA

\footnotetext{
${ }^{33}$ Millard Meiss, Jean Longnon and Raymond Cazelles, The 'Très Riches Heures' of Jean, Duke of Berry, 1969, New York, George Braziller, 1989, p. 48, p. 193.
} 